\title{
Aleukemic myeloid sarcoma of small intestine: Masquerading as Subacute Intestinal Obstruction: Review of Literature
}

\author{
Vidushi Joshi ${ }^{1}$, Gaurav PS Gahlot ${ }^{2 *}$, Ankur Ahuja ${ }^{2}$, Tathagata Chatterjee ${ }^{2}$ and Sunita BS $^{3}$ \\ ${ }^{1}$ Military Hospital Devlali Maharastra, India \\ ${ }^{2}$ Dept of Lab Sciences \& Mol Med, Army Hospital (R \& R) Delhi, India \\ ${ }^{3}$ Dept of Pathology Armed Forces Medical College Pune, India
}

\begin{abstract}
Background: Myeloid sarcoma (MS) is an extramedullary disease of immature myeloid cells with incidence of 1-2\% among all acute myeloid leukemia (AML) cases. Less than twenty cases of aleukemic MS with initial presentation as intestinal mass have been described in the English literature.

Case report: Here we report a case of 45 year old female with normal haematology workup who presented with acute abdominal pain and distension. On evaluation, she was found to have ileocolic intussusception of gangrenous bowel, so managed by limited right hemicolectomy and initially reported as Non Hodgkin lymphoma (NHL).During follow-up she was found to have a globular mass in right lumbar region that was diagnosed as myeloid sarcoma. On further followup, her TLC count was gradually increasing.

Conclusion: The index case highlights the unusual presentation of isolated intraabdominal MS which was clinical diagnosed as subacute intestinal obstruction in a young female with normal hematological profile.
\end{abstract}

Keywords: Myeloid sarcoma, Small intestine, Obstruction, Aleukemic, Myeloperoxidase , CD34

\section{Introduction}

Granulocytic sarcoma (GS) or myeloid sarcoma (MS) was first described by "Burns" in $1911 .{ }^{[1]} \mathrm{MS}$ occurs in pediatric/ young adults and can exist with AML/myelodysplastic syndrome (MDS) in $15-35 \%$ or as harbinger of AML in $50 \%$ or as relapse in a treated patient. ${ }^{[2-3]}$ In $25-30 \%$ cases, its aleukemic/isolated form also exists with the variable interval weeks to months between diagnoses of MS its development to AML. ${ }^{[4]}$ MS can be subclassified into granulocytic/monoblastic/myelomonocytic types depending upon maturation and cell types. ${ }^{[3,5]}$ In view of non-availability of standard treatment protocol for isolated MS as in our patient (blastic subtype); systemic chemotherapy with cytarabine and daunorubicin was offered. On follow up the patient is in complete remission without evidence of recurrent disease or AML. ${ }^{[2,6]}$ Isolated MS has better disease free survival as compared to EMD concurrent with AML or AML without MS. ${ }^{[2]}$ This case report emphasizes the awareness of this rare, aggressive disease with unusual presentation; as timely diagnosis led to appropriate management and good outcome.

\section{Case Report}

A 45 year old female presented with easy fatigability followed by acute abdominal pain and distension in July 2016. Clinical diagnosis of subacute intestinal obstruction was made. Her hematological work-up comprised of hemoglobin $12.1 \mathrm{gm} / \mathrm{dl}$, total leukocyte count (TLC) 8900/ cumm, differential leukocyte count (DLC) P63L29M3E5 and platelets $2.7 \times 10^{5} / \mathrm{cumm}$. During intraoperative limited right hemicolectomy procedure, an ileocolic intussusception with gangrenous bowel was observed. Histopathologic examination of this specimen revealed diffuse infiltrate of large, monomorphic, immature lymphoid cells suggestive of large cell Non-Hodgkin lymphoma (NHL). The patient was then referred to our hospital for further management. During evaluation, hemoglobin $11.7 \mathrm{gm} / \mathrm{dl}$, TLC 13,800/cumm, DLC: P71L24M3E2 and platelets counts of $2.2 \times 10^{5} /$ cumm were observed. CECT abdomen revealed a soft tissue mass measuring $38 \times 36 \times 32 \mathrm{~mm}$ with adjacent fat stranding in mesentery in right lumbar region at L2 level with multiple enlarged retroperitoneal and mesenteric lymph nodes. Whole body positron emission tomography-computed tomography (PET-CT) scan revealed a FDG avid conglomerate mass of mesenteric lymph nodes measuring 47x36×35 mm at L2L3 level with SUV of 6.9. Ultrasound guided FNAC was attempted from mesenteric lymph node however remained inconclusive due to scant cellularity. The patient then planned for exploratory laparotomy and omental biopsy. Intra-operatively, multiple small bowel loops were adhered to each other and with previous incisional line. Gross 
examination of the resected $3.0 \times 1.5 \times 0.8 \mathrm{cms}$ colectomy segment revealed a firm, nodular area of $1.5 \times 0.3 \times 0.2 \mathrm{cms}$ size with homogenous grey white cut surface and pin point foci of hemorrhage. Histopathological examination revealed diffuse infiltration of lamina propria, serosa, omentum, and perinodal adipose tissue with the neoplastic cells. These atypical monocytoid cells have folded nuclei, amphophilic cytoplasm and inconspicuous nucleoli. These tumor cells were immunopositive for CD45, CD34, MPO, CD117, Ki67 95\% and immunonegative for PANCK, EMA, CD79a, CD20, CD10 and CD3 thus a diagnosis of granulocytic sarcoma was confirmed. Postoperatively her TLC count raised abruptly upto 91,600/cumm with $80 \%$ blasts in peripheral blood smear and $90 \%$ blasts on bone marrow examination. On cytochemistry analysis, these blasts were positive for myeloperoxidase (MPO), nonspecific esterase (NSE); while negative for per iodic Schiff (PAS) stains. Flow cytometry, with CD45 gated population showed positivity for myeloid markers and negative lymphoid markers and suggestive of AML M2. Cytogenetic study showed abnormal cytogenetics with 47XX +22 [14]/46,XX.Extended workup for AML1/ ETO translocation, FLT3 Mutation, PML RARA were negative. RT-PCR and gel electrophoresis showed the hybrid transcript for CBFB/MYH11 and positive for inv16 mutations. She was therefore managed by induction chemotherapy with Indarucibin + Cytosine w.e.f. 01 Dec 2016. On follow up she is presently in complete remission and asymptomatic.

TABLES:

\begin{tabular}{|c|c|c|c|c|c|c|}
\hline Author & Patients & Age /Sex & Site & Symptoms & Treatment & Follow up \\
\hline Brugo et al., 1977 [3] & 1 & $38 / \mathrm{M}$ & Ileum, stomach & Small bowel obstruction & $\begin{array}{l}\text { Surgical resection, chemotherapy } \\
\text { (no Ara-C) }\end{array}$ & AML and death at 4 months \\
\hline Beck et al., 1984 [4] & 1 & $30 / M$ & lleum, cecum & Abdominal pain, vomiting & $\begin{array}{l}\text { Surgical resection, radiotherapy } \\
\text { (25Gy), chemotherapy (Ara-C) }\end{array}$ & $\begin{array}{l}\text { Complete remission }(\mathrm{CR}) \text { at } \\
4 \text { years }\end{array}$ \\
\hline Meis et al., 1986 [2] & 2 & $\begin{array}{l}16 / \mathrm{F} \\
31 / \mathrm{M}\end{array}$ & $\begin{array}{l}\text { Small intestine } \\
\text { Ileum, mesentery }\end{array}$ & $\begin{array}{l}\text { Abdominal pain, distension } \\
\text { Small bowel obstruction }\end{array}$ & $\begin{array}{l}\text { Chemotherapy (Ara-C) } \\
\text { Chemotherapy (Ara-C) }\end{array}$ & $\begin{array}{l}\text { CR at } 6 \text { years } \\
\text { AML at } 8.5 \text { months, } C R \text { at } \\
8 \text { years }\end{array}$ \\
\hline Toki et al., 1987 [5] & 1 & $51 / \mathrm{M}$ & lleum & Small bowel obstruction & $\begin{array}{l}\text { Surgical resection, chemotherapy } \\
\text { (Ara-C) }\end{array}$ & $\begin{array}{l}\text { AML at } 9 \text { months, death at } \\
19 \text { months }\end{array}$ \\
\hline Russell et al., 1988 [6] & 1 & $49 / \mathrm{M}$ & $\begin{array}{l}\text { Small intestine, } \\
\text { mesentery }\end{array}$ & Small bowel obstruction & $\begin{array}{l}\text { Surgical resection, chemotherapy } \\
\text { (Ara-C), bone marrow transplantation } \\
\text { (BMT) }\end{array}$ & $\begin{array}{l}\text { AML at } 8 \text { months, CR at } 25 \\
\text { months }\end{array}$ \\
\hline Grange et al., 1988 [7] & 1 & $38 / F$ & lleum & Small bowel obstruction & Chemotherapy, BMT & $\begin{array}{l}\text { AML at } 8 \text { months, } C R \text { at } 40 \\
\text { months }\end{array}$ \\
\hline Friiedrich et al., 1989 [8] & 1 & $38 / M$ & $\begin{array}{l}\text { Ileum, mesentery } \\
\text { obstruction }\end{array}$ & Small bowel obstruction & Surgical resection & Postoperative death ( sepsis) \\
\hline Kowal-Verm et al., 1991 [9] & 1 & 8/M & lleum & Small bowel obstruction & $\begin{array}{l}\text { Surgical resection, chemotherapy } \\
\text { (Ara-C), irradiation, BMT }\end{array}$ & CR at 4 years \\
\hline Corpechot et al., 1998 [10] & 1 & $40 / \mathrm{M}$ & Jejunum & Small bowel obstruction & $\begin{array}{l}\text { Surgical resection, chemotherapy } \\
\text { (Ara-C), BMT }\end{array}$ & $\begin{array}{l}\text { AML at } 21 \text { months, CR at } 31 \\
\text { months }\end{array}$ \\
\hline Zhou et al., 2001 [11] & 1 & $32 / \mathrm{M}$ & $\begin{array}{l}\text { Small intestine, } \\
\text { mesentery }\end{array}$ & $\begin{array}{l}\text { Small bowel obstruction, } \\
\text { weight loss }\end{array}$ & $\begin{array}{l}\text { Surgical resection, chemotherapy } \\
\text { (Ara-C), BMT }\end{array}$ & AML at 14 months \\
\hline Yamauchi et al.,2002 [12] & 1 & $39 / \mathrm{M}$ & lleum & Abdominal pain & Surgical resection & AML at 6 months \\
\hline Xavier et al., 2003 [13] & 1 & $36 / M$ & lleum, mesentery & Minor intestinal obstruction & $\begin{array}{l}\text { Surgical resection, chemotherapy } \\
\text { (Ara-C), BMT }\end{array}$ & CR at 14 months \\
\hline Mrad et al., 2004 [14] & 1 & $13 / F$ & $\begin{array}{l}\text { Small intestine, } \\
\text { mesentery }\end{array}$ & Abdominal mass & $\begin{array}{l}\text { Surgical resection, chemotherapy } \\
\text { (Ara-C) }\end{array}$ & CR at 27 months \\
\hline Wong et al., 2005 [15] & 1 & $36 / M$ & lleum & $\begin{array}{l}\text { Subacute intestinal } \\
\text { obstruction }\end{array}$ & $\begin{array}{l}\text { Surgical resection, chemotherapy } \\
\text { (Ara-C) }\end{array}$ & CR at 1 year \\
\hline Venizelos et al., 2008 [16] & 1 & $60 / F$ & lleum & Small bowel obstruction & $\begin{array}{l}\text { Surgical resection, chemotherapy } \\
\text { (Ara-C) }\end{array}$ & CR at 6 months \\
\hline Alvarez et al., 2011 [17] & 1 & $41 / \mathrm{M}$ & $\begin{array}{l}\text { Small bowel, } \\
\text { greater omentum }\end{array}$ & Small bowel obstruction & $\begin{array}{l}\text { Surgical resection, radiotherapy, } \\
\text { chemotherapy }\end{array}$ & - \\
\hline Kwan et al., 2011 [18] & 1 & $39 / F$ & lleum & $\begin{array}{l}\text { Non bloody diarrhoea, } \\
\text { abdominal pain }\end{array}$ & Chemotherapy, surgical resection & Disease free for 2 years \\
\hline
\end{tabular}




\begin{tabular}{|l|l|l|l|l|l|l|}
\hline Author & Patients & Age /Sex & Site & Symptoms & Treatment & Follow up \\
\hline Yang Chi et al., 2008 [19] & 1 & $30 / \mathrm{M}$ & lleum, cecum & $\begin{array}{l}\text { Abdominal pain, vomiting } \\
\text { (small bowel obstruction) }\end{array}$ & $\begin{array}{l}\text { Surgical resection and chemotherapy } \\
\text { (Busulfan, cyclophosphamide and } \\
\text { Ara-C) }\end{array}$ & - \\
\hline Clcilet et al., 2017 [20] & 1 & $45 / \mathrm{F}$ & lleum & $\begin{array}{l}\text { Subacute intestinal } \\
\text { obstruction }\end{array}$ & $\begin{array}{l}\text { Surgical resection, chemotherapy } \\
\text { (Ara-C) }\end{array}$ & - \\
\hline Present case [21] & 1 & $45 / \mathrm{F}$ & Small intestine & $\begin{array}{l}\text { Subacute intestinal } \\
\text { obstruction }\end{array}$ & $\begin{array}{l}\text { Surgical resection, chemotherapy } \\
\text { (Ara-C) }\end{array}$ & CR at 6 months \\
\hline
\end{tabular}

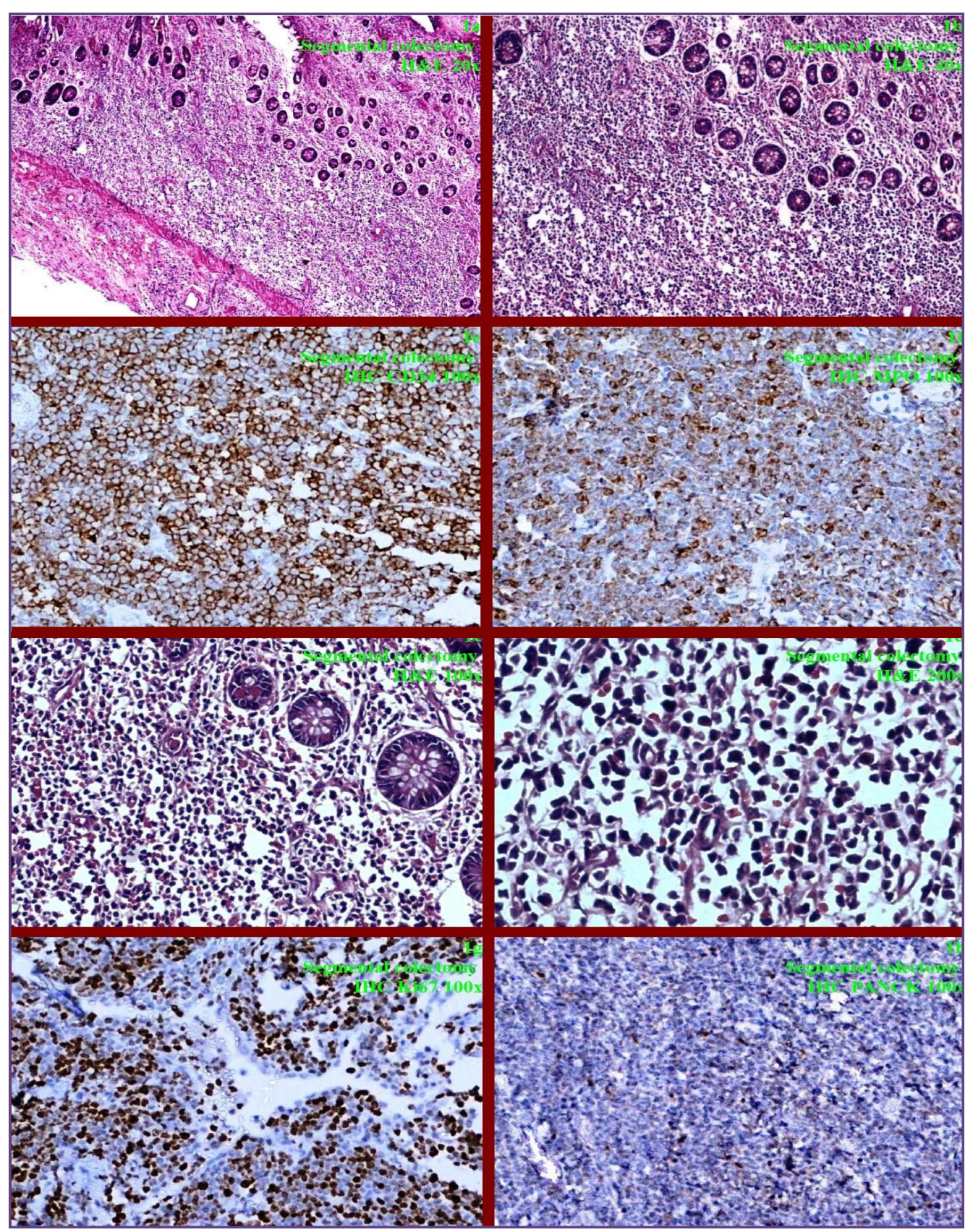

Fig. 1: Dense monomorphic atypical lymphoid cells with lymphoepithelial and lamina propria of colon (1a;20x, 1b;40x). Tumor cells have round nuclei and condensed chromatin (1c;100x, 1d;200x) Tumor cells are immunopositive for CD34 (1e; 100x), MPO (1f;100x), high Ki67 (1g;100x) while negative for PANCK (1h;100x). 


\section{Discussion}

Myeloid sarcoma (MS) or granulocytic sarcoma (GS) or Myelosarcoma or Extramedullary myeloblastic disease (EMD) or Myeloblastoma also had been termed "Chloroma" (Chlor=green, oma=tumor) by King in 1853 owing to its green color attributed to the enzyme myeloperoxidase. This green color gets faded on exposure to air and lost with formalin fixation. ${ }^{[7]}$ WHO defines MS as "tumor mass comprising of myeloid blasts without maturation occurring at an anatomic site; other than the bone marrow'. MS occurs in 2 per $1,000,000$ adults \& 0.7 per $1,000,000$ children with wide age range of 1-81 years. ${ }^{[8]}$ Common EMD sites include skin, subperiosteal bone, lymph nodes with unusual involvement of peritoneum, central nervous system, oral-nasal mucosa, breast, genitourinary tract, chest wall, pleura, retroperitoneum and gastrointestinal system. ${ }^{[2-3,6,9]} 6.5 \%$ of MS occur in the gastrointestinal tract with further rarity as occurrence in isolated aleukemic forms. Gastrointestinal MS cases present with abdominal discomfort, vomiting and pain depending upon its size that ranges from 2-20 cms. ${ }^{[10]}$ Complications of gastrointestinal MS are intestinal obstruction, perforation or intussusception. Stefanidakis et al in 2009 suggested that EMD represents an ability of leukemic blasts to invade the surrounding tissues and showed that specific interaction between the matrix metalloproteinase (MMP)-9 and leukocyte surface $\beta 2$ integrin is required for the migration of AML-derived cells. ${ }^{[1]}$ Computed tomographic features as focal bowel wall thickening or polypoidal mass with intraluminal or exophytic components mimic with lymphoma or primitive neuroectodermal tumor. Histomorphology shows diffuse or Indian file pattern with high mitotic activity and may initially be misdiagnosed as high grade lymphoma, Burkitt's lymphoma, Ewing's sarcoma, rhabdomyosarcoma, neuroblastoma, undifferentiated carcinoma, malignant melanoma, extramedullary hematopoiesis or inflammation. ${ }^{[3,12]}$ Multiple modalities including immunohistochemical stains, conventional cytogenetics, fluorescent in situ hybridization cytogenetics, and flow cytometry assist to finalize the diagnosis of aleukemic isolated MS. Immunohistochemistry for CD 34, MPO, CD117, CD13, CD33, Ki67 are common markers in tumors with myeloid differentiation whereas CD14, CD11c and CD163 favors monoblastic differentiation. In addition, Pancytokeratin, vimentin, S100, Tdt, CD3, CD20, CD79a, CD10, Bc16, MUM1, lysozyme, CD56, CD61, CD30 and glycophorin should be added to exclude other differential diagnosis. Accurate initial diagnosis of isolated aleukemic MS was offered only in $53 \%$ cases, others being misdiagnosed as NHL. ${ }^{[13]}$ Cytogenetic abnormality has been observed in $50 \%$ of cases with prevalence of translocation $\mathrm{t}(8 ; 21)$ in $8-35 \%$ cases. The index case showed trisomy 22 and inversion 16..$^{[2,3]} \mathrm{MS}$ has been treated with systemic chemotherapy (Cytarabine based), surgical resection, radiation therapy, and peripheral stem cell/bone marrow transplantation reported to prolong disease free survival. ${ }^{[2,3,6,14]}$ For diagnosis and follow-up during treatment, PET scan with 18-FDG PET-CT scan is a sensitive investigation of choice to monitor response of treatment and to pick up any residual disease. Definitive diagnosis of MS has great prognostic significance as it can transform to AML if not treated in time.

\section{Conclusion}

Here we an extremely rare aleukemic isolated case of MS of small intestine. A high index of suspicion is required when confronted with poorly differentiated lesions. A multidisciplinary approach is advised to confirm its definitive diagnosis and to predict the best outcome and survival. Myeloid sarcoma is often a precursor to a diagnosis of AML; therefore needs an urgent systemic chemotherapy and/or any combination of surgical resection, radiotherapy, or stem cell transplantation.

\section{Acknowledgements}

Our patient

\section{Funding}

No funding is involved

\section{Competing Interests}

There is no competing interests

\section{Reference}

1. Burns A: Observations of Surgical Anatomy in Head and Neck. Thomas Royce and Company, Edinburgh, UK. 1811:364-66.

2. Tsimberidou, A.M., Kantarjian, H.M., Wen, S., Keating, M., O'Brien, S., Brandt, M. et al. Myeloid sarcoma is associated with superior event free survival compared with acute myeloid leukemia. Cancer 2008;113:1370-78.

3. Pileri, S.A., Ascani, S., Cox, M., Campidelli, C., Bacci, F., Piccioli, M. et al. Myeloid sarcoma: clinicopathologic, phenotypic and cytogenetic analysis of 92 adult patients. Leukemia 2007;21:340-50.

4. Vardiman, J.W., Thiele, J., Arber, D.A., Brunning, R.D., Borowitz, M.J., Porwit, A. et al. The 2008 revision of the World Health Organization (WHO) classification of myeloid neoplasms and acute leukemia: rationale and important changes. Blood 2009;114:937-51.

5. Brunning RD, Matutes E, Flandrin G, et al. Acute myeloid leukaemia not otherwise categorised. In: Jaffe ES, Harris NL, Stein H, Vardiman JW, editors. WHO classification of tumours of haematopoietic and lymphoid tissues. Lyon: IARC Press 2001;22(8):104-05. 
6. Burnett, A., Wetzler, M. and Lowenberg, B. Therapeutic advances in acute myeloid leukemia. J Clin Oncol 2011;29:487-94.

7. King A: A case of chloroma. Monthly J Med 1853;17:97.

8. Breccia M, Mandelli F, Petti MC, D'Andrea M, Pescarmona E, Pileri SA, Carmosino I, Russo E, De Fabritiis P, Alimena G. Clinico-pathological characteristics of myeloid sarcoma at diagnosis and during follow-up: report of 12 cases from a single institution. Leuk Res 2004; 28:1165-69.

9. Yu T, Xu G, Xu X, et al. Myeloid sarcoma derived from the gastrointestinal tract: a case report and review of the literature. Oncol Lett 2016;11:4155-9.

10. Venizelos ID, Frakandreas G, Tatsiou ZA, et al. Isolated myeloid sarcoma of the small intestine in an aleukemic Patient-Case Report and Review of the Literature. Visc Med 2008;24:171-4.
11. Stefanidakis, M., Karjalainen, K., Jaalouk, D.E., Gahmberg, C.G., O'Brien, S., Pasqualini, R. et al. Role of leukemia cell invadosome in extramedullary infiltration. Blood 2009;114: 3008-17.

12. Paydas, S., Zorludemir, S. and Ergin, M. SGranulocytic sarcoma: 32 cases and review of the literature. Leuk Lymphoma 2006;47:2527-41.

13. Yamauchi, K. and Yasuda, M. Comparison in treatments of nonleukemic granulocytic sarcoma: report of 2 cases and a review of 72 cases in the literature. Cancer 94: 1739-46.

14. Avni, B.R., Rund, D., Levin, M., Grisaro, S., Ben-Yehuda, D. and Paltiel, O. Clinical implicationsof acute myeloid leukemia presenting as granulocytic sarcoma. Hematol Oncol, in press. 2011.

*Corresponding author:

Dr. GPS Gahlot, MD, Oncopathology Fellowship, Associate Professor, Department of Lab Sciences and Mol Medicine, Army Hospital (R\&R) Delhi Cantt, New Delhi-110010 INDIA

Phone: +91 9968968454

Email: gpsinghgahlot@gmail.com

Date of Submission : 14/12/2019

Financial or other Competing Interests: None. 